\title{
著者とキーワードの関連性に着目した 研究領域ブラウジングシステムの試作 A Prototype for a Research Area Browsing System focusing on Author-Keyword Relationship
}

\author{
レボウィッツ紀子松村敦宇陀則彦 \\ Noriko LEBOWITZ, Atsushi MATSUMURA, Norihiko UDA
}

筑波大学大学院 図書館情報メディア研究科

Graduate School of Library, Information and Media Studies, University of Tsukuba

E-mail: \{nlebo,matsumur,uda\}@slis.tsukuba.ac.jp

新しい研究領域に取り組もうとしている研究者は, 文献調査により対象領域の研究内容につい て把握する .しかし, 研究領域を把握していない段階では情報要求に曖昧性が生じ, 効率的な文 献調査を行なうことができない .この問題を解決するには , 文献調査の前段階において対象とす る研究領域の全体像を把握し，さらに個々の研究テーマを概観できる機能が必要であると考える． 本稿では，著者と著述文献キーワードの関連性を利用して，各著者の研究内容の傾向を読み取り， それを研究テーマとして解釈し，研究領域をブラウジングする手法を提案する．また，提案手法 に基づいて試作したシステムを紹介する．

A researcher studies a new target domain through a search of papers. However, an efficient search is difficult if the information demands are ambiguous. To solve this problem, it is necessary prior to a search of the papers to have an understanding of the entirety of the research field and an overview of the research topics. In this paper, we propose a technique to extract the research topics by using authorkeyword relationship in a specified research area. And we introduce the prototype system based on our proposal technique.

キーワード：研究領域, ブラウジングシステム, ISP モデル , PubMed, MeSH , Research Area , Browsing System , Information Seeking Process Model

\section{1 はじめに}

これから新しい領域で研究に取り組もう としている研究者の多くは, 文献調査によ り対象とする研究領域の全体像を把握した
上で研究内容を具体化していく．この際, 検 索システムを用いるのであれば, ユーザは 情報要求を的確なキーワードとして表現す る必要がある。しかし, ユーザが研究領域 について把握していない段階では情報要求 


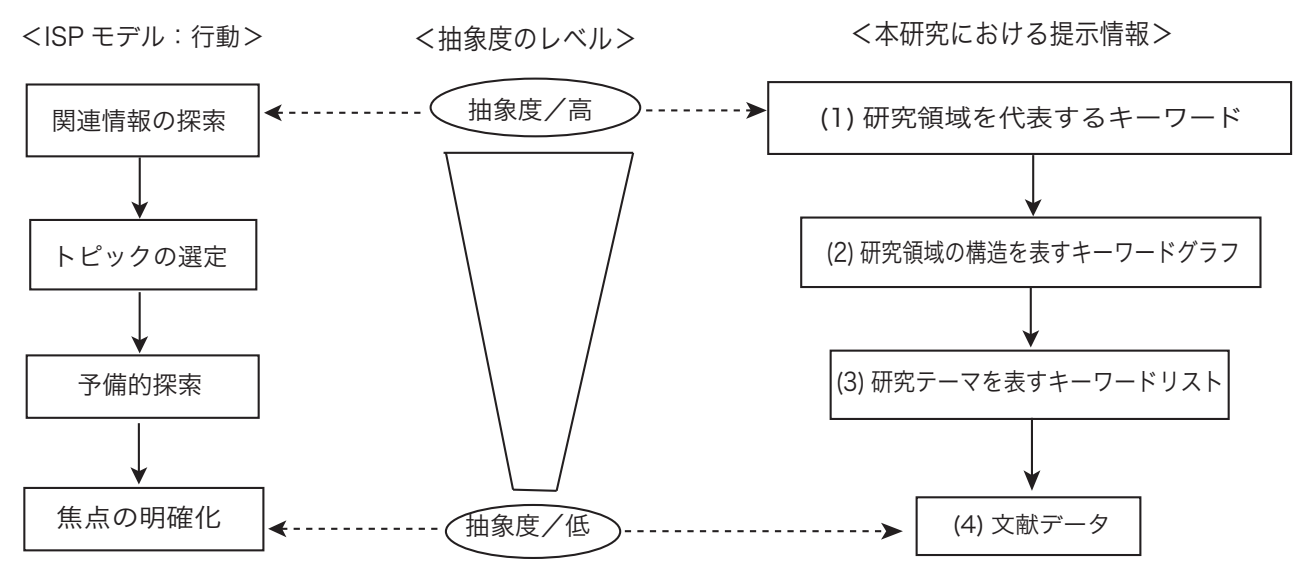

図 1: 本研究における提示情報の抽象度についての定義

に曖昧性が生じるため, 的確なキーワード の選択が難しく，抽象度の高いキーワード を用いた検索となる. 光の結果，提示され る文献データの数が膨大になり，適合文献 の判定が困難になるという問題が生じる .

本研究では, この問題の原因をユーザの 情報要求とシステムにより提示される情報 との間にある抽象度の不一致と捉え, クー ルソのISP モデル [1][2]に沿って , ユーザの 情報要求に応じた抽象度の情報を提示する 仕組みを提案する . 具体的には, 研究領域 におけるキーワードを関連づけて提示する ことで全体像の把握を促し, 兴の上で, 著者 と著述文献のキーワードを関連づけて研究 テーマとして提示することで，暧昧なユー ザの情報要求を段階的に特定化させること を試みる。以下では, 提案手法の詳細と，光 れに基づいて試作した研究領域ブラウジン グシステムについて説明する .

\section{2 提案手法}

クールソは情報探索過程について探索開 始, 選択, 探求, 焦点形成, 収集, 表現とい

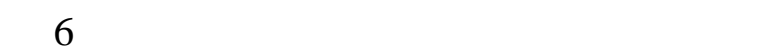
おける感情·思考·行動の変化を Information Seeking Process(ISP) モデルとして表現して いる。本研究の提案手法は, このISP モデ ルのうち探索開始から焦点形成までを対象 とする. 文献選択を行うブラウジングの過 程において提示する情報の抽象度を ISP モ デルの行動に沿った形で段階的に下げるこ とにより, ユーザの情報要求の曖昧性を解 消することを試みる．提示情報の抽象度と して以下の 4 段階を設定した .

(1) 研究領域を代表するキーワード

(2) 研究領域の構造を表すキーワードグラフ

(3) 研究テーマを表すキーワードリスト

(4) 文献データ 


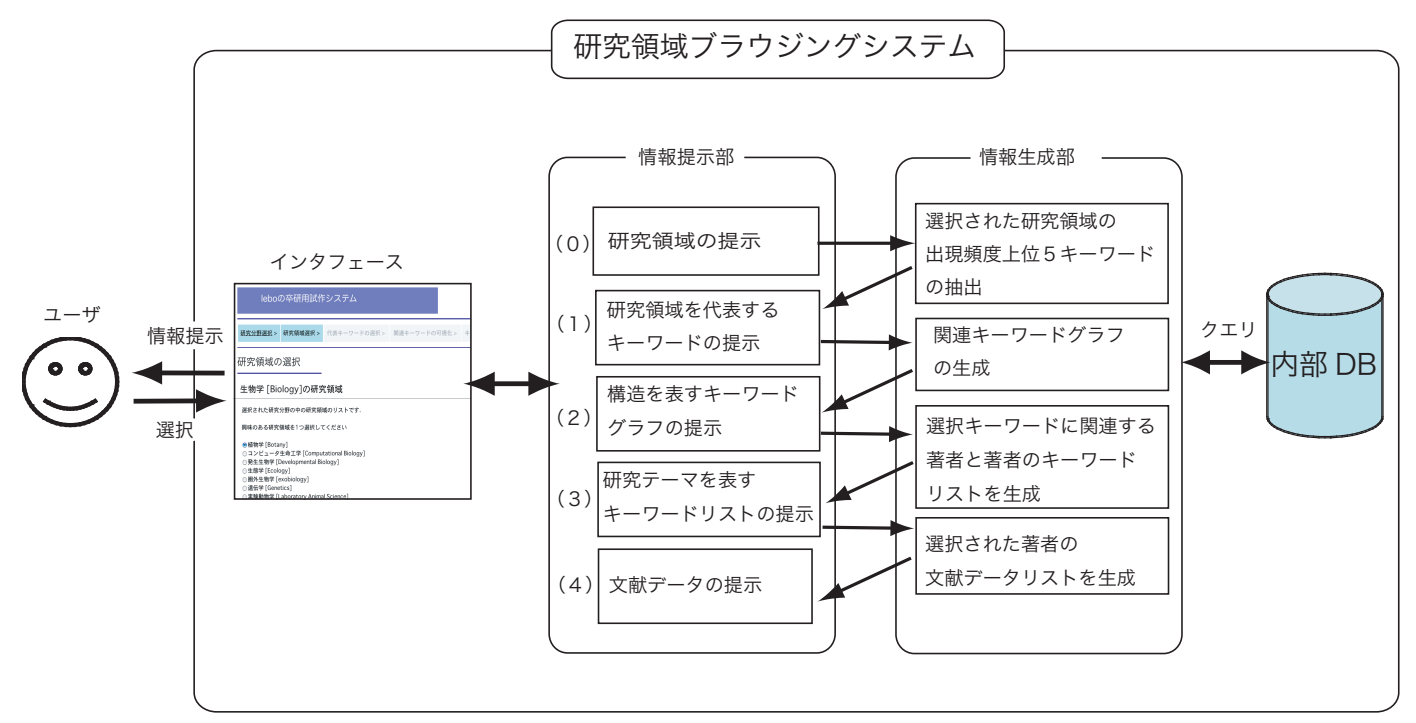

図 2: 試作システムの処理の流れ

斉藤 [3]により具体化されているISP モデ ルでの探索開始から焦点形成おける「行動」 と, 本研究で提示する情報の抽象度を対応 付けたものを图 1 に示す.まず(1)では，ブ ラウジングを開始するユーザの最初の手が かりとなる研究領域を代表するキーワード を提示する. 兴の上で，(2)では研究領域を 代表するキーワードと关れに関連するキー ワードをグラフ構造により可視化して提示 する . ユーザは可視化されたキーワード間 の関連を繰り返しブラウズすることで, 研 究領域の構造を知ることができる.これは ISP モデルにおける「関連情報の探索」から

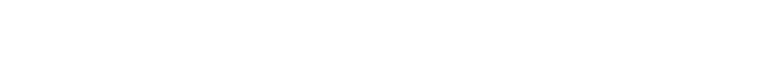
(3)では, 著者と著述文献のキーワードを関 連づけ, 研究領域における研究テーマとし て著述の多い著者の順に提示する .これは ISP モデルにおける「予備的探索」の段階 となるものである . 著者と著述文献のキー ワードを関連づけて提示することで, ユー
ザは著者ごとに研究領域の傾向がわかる．

研究領域の傾向を把握するためには, 通 常多数の文献を読む必要があるが, 実際に は関係のない文献も多く含まれており，非 効率的である.研究領域に強い影響を与え ている文献から読むことができれば，効率 よく傾向を把握できる. 乥こで本研究では， 研究領域の主要なキーワードを含み，かつ 著述数の多い著者の文献を影響の強い文献 と仮定した.実際に植物学に関する文献デー タから著者とキーワードを抽出して分析し た結果, 著述の多い上位約 $20 \%$ の著者の文 献には研究領域の約 $80 \%$ \%キーワードが含 まれていることがわかった .このことは, 著 述の多い著者の文献が研究領域の傾向に強 い影響を及ぼしていることを示している． 


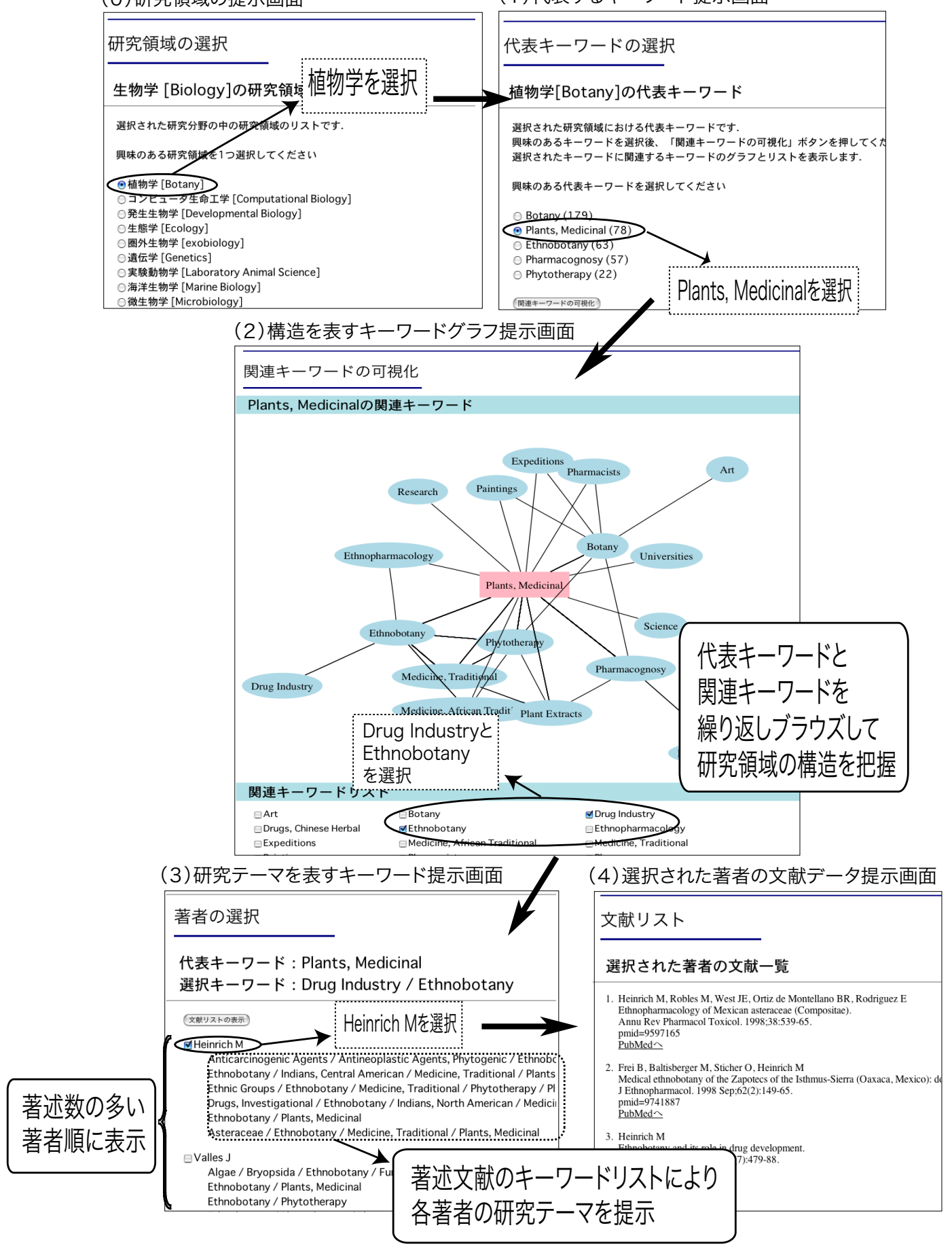

図 3: 試作システム上での情報探索の流れ 


\section{3 研究領域ブラウジングシステム}

提案手法に基づいて, 対象とする研究領 域の把握と適合文献選択の際のブラウジン グを支援するシステムを試作した .

試作システムの構筑には, PubMed[4] の 文献データを用いた．PubMed の文献デー タには階層構造を持つ MeSH(Medical Subject Headings)[5] タームと呼ばれる索引語が 付与されているため，これをキーワードと して扱った . MeSH タームの階層構造にお いて，Biology (生物学) の下位概念である Botany(植物学) を研究領域として設定した。 次にシステムにおける処理の流れを図 2 に 示す. また図 3 には試作システムのインタ フェースを用いて , システム上での情報探 索の流れを示す .

次に，各段階における処理の流れについ て説明する。

\section{研究領域の提示}

研究領域の提示はシステム利用の出発 点である . 本システムでは, MeSH の 階層構造と MeSH タームを利用して研 究領域の設定を行なった . ユーザによ り研究領域が選択されると, システム 側では検索対象を弚のキーワードを持 つ文献データとする .

代表キーワードの提示

決定された検索対象の範囲において, 出 現頻度の高い順に5つのキーワードを 研究領域を代表するキーワードとして 抽出し提示する [図 3-(1)] . ユーザはこ れらのキーワードから興味のあるもの を一つ選択する。
キーワード間の関連を表すグラフの提示 前段階でユーザにより選択されたキー ワードと同一文献内に共起するキー ワードとを関連づけて, グラフとして 可視化する [図 3-(2)] . ユーザは, 研究 領域を代表するキーワードと構造を表 すキーワードのグラフを繰り返しブラ ウズし，これらのキーワードの中から， 情報要求に合致するものを選択する .

研究テーマを表すキーワードリストの提示 ユーザにより選択されたキーワードを 著述文献に持つ著者のリストを生成す る [図 3-(3)] . このリストは著者名と著 述文献のキーワードリストで構成され ており，これを研究テーマとして著述 数の多い順に提示する.ユーザは提示 された研究テーマのリストをブラウズ して自分の興味に近い研究を行ってい る著者を選択する。

文献データの提示

ユーザにより選択された著者の著述文 献リストを提示する[图3-(4)] .さらに， テストデータの入手先である PubMed 上のデータへのリンクも提示する.ユー ザはこのリンク部分をクリックするこ とで, PubMed 上の該当データに移るこ とができる .

以上か試作システムによる一連の処理の 流れである .

\section{4 おわりに}

本研究では, 学術情報アクセスを対象と して, 情報要求に適した抽象度の情報を提 
示する仕組みを提案し，乥れに基づいてシ ステムを試作した . 研究領域を把握すると いう観点から，著者と著述文献のキーワー ドの関連性を利用して, 研究テーマの提示 を行なった .

今後の課題は, システムが各段階で提示 する情報の妥当性の評価である．弚のため には, まず, 提示する情報に抽象度を設定 したことによる効果について調査を行なう 必要がある。また, 特に, 研究テーマの抽 出に関して検討を行い, 研究者の文献選択 の支援を行える，より実用的な手法を得た いと考えている .

\section{参考文献}

[1] Carol C. Kuhlthau. "Inside the Search Process: Information Seeking from the User's Perspective". Journal of the American Society for Information Science. vol. 42, no. 5, 1991, p. 361-371.

[2] 渡辺智山. “利用者研究史と情報探索過 程モデル”. 同志社図書館情報学. 第 7 号, 1996, p. 38-74.

[3] 斎藤泰則. “3 情報探索の論理”. 情報探 索と情報利用. 東京. 勁草書房. 2001, p. 153-188. (図書館・情報学シリーズ２) (ISBN 4-326-04801-8).

[4] U.S. National Library of Medicine. PubMed. 更新 2007-04-25. (才 ンラインデータベース), 入手先 $<$ http://www.pubmed.gov>, （参照 2007-04-25).
[5] U.S. National Library of Medicine. Medical Subject Headings. 1999, 更新 2006-07-25. (オンラインデータベース), 入手先<http://www.nlm.nih.gov/mesh/>, (参照 2007-04-27). 